Stewart was a master in the art of lecturing. His easy and lucid style, combined with a rare power of swift and effective drawing on the blackboard, would have made his addresses notable quite apart from the peculiar charm of his delivery.-The Morning Post, Saturday, September 28th, 1907.

\title{
EDMUND MOJSISOVICS VON MOJSVAR, Sc.D.
}

We regret to record the death at Mallnitz, on the 2nd October, of the eminent Austro-Hungarian geologist and palæontologist, Johann August Georg Edmund Mojsisovics, Edler von Mojsvár, Sc.D. Camb., Foreign Memb. Geol. Soc. Lond., author of numerous memoirs on the Cephalopoda of the Austrian Trias, to the description and illustration of which he deroted very many years of his life. He was a member of the k.k. Geologischen Reichsanstalt in Vienna; and usually resided at Strohgasse, 26, Vienna 3/3. We hope to give a fuller notice of Dr. E. Mojsisovics later on.

\section{REV. RICHARD BARON, F.L.S., F.G.S. BorN 1847. Died ОстоBer 12, 1907.}

$W_{E}$ regret to record the death (from heart-failure, following an attack of malarial fever) of the Rev. Richard Baron, who for thirtyfive years was engaged in missionary work at Antananarivo, Madagascar, in connection with the London Missionary Society. Mr. Baron was a frequent contributor to the Antananarivo Annual, and took an earnest interest in the botany, geology, and palæontology of Madagascar. In March, 1889, he communicated to the Geological Society of London, through the Director-General of the Geological Survey, some interesting notes on the geology of Madagascar, with an appendix on some fossils collected by him, by Mr. R. Bullen Newton, F.G.S., of the British Museum (Natural History). At the same meeting, March 6th, 1889, Dr. F. H. Hatch, F.G.S., contributed some notes on the petrographical characters of some rocks collected by Mr. Baron (GeoL. MAG., 1889, pp. 234-235, and Quart. Journ. Geol. Soc., 1889, vol. xiv, pp. 305-331, pl. xiii, and map). A second extensive collection of Invertebrate fossils was made by Mr. Baron in 1891, during a journey of 1,200 miles, in which he visited the east coast, the northern end of Madagascar, and the north-west coast and adjacent islands. His description of the geology and the rocks examined form the subject of an excellent paper read before the Geological Society, November 21st, 1894 (Quart. Journ. Geol. Soc., vol. li, 1895, pp. 57-71, pl. i), to which Mr. R. B. Newton contributed a description of the fossils obtained by Mr. Baron (op. cit., pp. 72-92, pls. ii and iii).

From Mr. Baron's observations and collections we learn that sedimentary rocks occur mainly on the western and southern sides of the island. From the fossils brought home it appears that the following formations are represented, namely: Eocene, Upper Cretaceous, Neocomian, Oxfordian, Lower Oolitic, and Liassic rocks. 
Possibly some of the slaty beds may prove to be of Silurian or Cambrian age. Recent deposits fringe the coast and are largely developed on the southern part of the island. The alluvial and peat deposits and old lake-bed accumulations have been largely explored by Dr. C. I. Forsyth Major and later by Mr. Standing, and have yielded numerous genera of Nesopithecus, Megaladapis, Hippopotamus, Crocodilia, Chelonia, Epyornis, etc. Mr. Baron also discovered the fossil remains of one of those long-snouted Gavial-like Crocodilia, considered to be of Lower Oolitic age, which was described and figured by Mr. R. B. Newton in the Geoc. MAG., 1893, pp. 193-198, Pl. IX, under the name of Steneosaurus Baroni.

It is interesting to mention that in the rocks described in 1889 by the Rev. Richard Baron as Jurassic in North-West Madagasear, the remains of a Sauropodous Dinosaur, referred by Mr. R. Lydekker to Bothriospondylus Madagascariensis, should have been obtained by Mr. J. L. Last, closely resembling forms found near Oxford, also at Fletton, near Peterborough, and in the Kimeridge Clay of Wiltshire (see Quart. Journ. Geol. Soc., 1895, vol. li, pp. 329-336).

Mr. Baron furthermore communicated to the Linnean Society a valuable paper on "The Flora of Madagascar" (Journ. Linn. Soc. Bot., vol. $\operatorname{xxv}, 1888$, pp. 246-350), and was the author of the first geological textbook in Malagasy, 1896, pp. 191, with numerous illustrations in the text, a copy of which is preserved in the Geological Department of the British Museum.

In 1891 the Council of the Geological Society of London marked their appreciation of Mr. Baron's geological work in Madagascar by the award of the balance of the proceeds of the Murchison Geological Fund, in testimony of the interest taken by them in the geological work which amid many discouragements he was carrying on in Madagascar.

Geologists owe a great debt of gratitude to such men as the Rev. Richard Baron and Mr. Standing in Madagascar, and the Rev. Samuel Couling, M.A., at Ching-chou-fu, Kiao-chow, North China, who in such distant regions and amid inimical surroundings have, with but little encouragement, carried on most valuable scientific researches and stimulated others to follow where they have led the way.

\section{MISOEIIAINEOUS.}

Serviço Geologico e Mineralogico do Brazil. -By a decree approved January 10th, 1907, the Federal Government of Brazil has established a Geological Survey with the title of Serviço Geologico e Mineralogico do Brazil, as a bureau of the Department of Industry, Highways, and Public Works. The service has already been organized, and systematic work has been commenced. The results of the Survey's work will be published as rapidly as possible. Communications and exchanges should be addressed to the office of the service at No. 49, Rua da Quitanda, Rio de Janeiro, Brazil. Orville A. Derby, Chief. 